\title{
Development of Interactive Story Book For Ecoliteration Learning to Stimulate Reading Interest in Early Grade Students Elementary School
}

\author{
Hendratno $^{1^{*}}$, Yoyok Yermiandhoko ${ }^{2}$, Fajar Nur Yasin ${ }^{3}$ \\ 1,2Universitas Negeri Surabaya, Surabaya, Indonesia \\ 3 Universitas Nahdlatul Ulama Sidoarjo, Sidoarjo, Indonesia
}

\begin{tabular}{|c|c|}
\hline 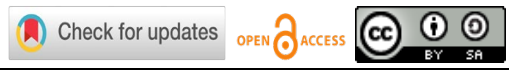 & DOI : https://doi.org/10.46245/ijorer.v3i1.179 \\
\hline Sections Info & ABSTRACT \\
\hline & \multirow{12}{*}{$\begin{array}{l}\text { Research aims to produce a storybook containing ecoliteracy education for } \\
\text { elementary school students of good quality in terms of the validity, } \\
\text { practicality, and effectiveness of a product. This type of research is Research } \\
\text { and Development with the ADDIE model. The instruments used were } \\
\text { validation questionnaires, observations, teacher response questionnaires and } \\
\text { learning outcomes tests. The results of this study indicate that the validation of } \\
\text { interactive storybooks for ecoliteracy learning gets an average coefficient of } \\
\text { validation from the validator, which is very valid qualifications. The } \\
\text { practicality of loading the teacher's response questionnaire gets a percentage } \\
\text { of } 97 \% \text {, the results of teacher and student observations get a percentage of } 91 \% \\
\text { and } 94 \% \text {. The effectiveness based on giving pretest and posttest to students } \\
\text { amounted to } 30 \text { students in grade } 1 \text { and } 30 \text { students in grade } 2 \text { with an average } \\
\text { pretest result of } 74, \text { while the average posttest was } 90.8 \text {. The result indicates } \\
\text { that there is a significant difference in the learning outcomes of early grade } \\
\text { elementary school students using interactive story books. Based on the } \\
\text { validation of the instrument and the recapitulation of the questionnaire filled } \\
\text { in by the teacher, it can be stated that the quality of the interactive storybooks } \\
\text { developed are very valid, practical and effective for use in learning. This } \\
\text { interactive storybook can help early grade elementary school teachers in } \\
\text { growing interest in reading related to ecoliteracy learning so that students' } \\
\text { awareness of caring for and caring for the surrounding environment can be } \\
\text { carried out from an early age. }\end{array}$} \\
\hline November 20, 2021 & \\
\hline Final Revised: January 6, 2022 & \\
\hline & \\
\hline ry 31,2022 & \\
\hline & \\
\hline & \\
\hline Ecoliteration Learning & \\
\hline & \\
\hline & \\
\hline & \\
\hline & \\
\hline
\end{tabular}

\section{INTRODUCTION}

Literacy is a basic ability that every individual must have in life. The function of literacy is not only for self-development but also for making individuals able to behave, act, and make the right decisions related to the context of life and life. Literacy is defined as an activity of reading and writing but literacy is also interpreted as a complex cognitive activity in communication and problem solving related to social and cultural contexts (Abidin et al., 2017). In relation to learning in elementary schools, literacy skills are divided into receptive skills, namely listening and reading and productive skills, namely writing and speaking skills. From these explanations, it can be said that basically the literacy process is divided into two stages, namely early literacy and advanced literacy. In early literacy students learn about how to catch codes, while in advanced literacy students interpret codes and then respond to them. In connection with the above, Elementary Schools (i.e. SD) in Indonesia provide early literacy programs in grades 1,2, and 3 where the basic competencies include listening, reading, speaking, and technical writing (Tryanasari \& Kartikasari, 2021)

In 2020, many major decisions will have to be made to reset the relationship between humans and nature. Because, globally nature has declined at an unprecedented rate. Nearly one million species are at risk of extinction due to human activities. 
Deforestation and forest fires that occur in various parts of the world including Indonesia, have killed billions of animals, destroyed lives, and wiped out large areas of forest. The water cycle is disturbed. An official study by the Indonesian government has predicted that Java Island will lose almost all sources of clean water by 2040 (Utama, 2019). For the first time in the planet's history, humans are the drivers of climate and environmental change, scientists call the Anthropocene (Waughray \& Nath, 2020).

Humans must be able to understand the working system of the earth and live in harmony with it. Otherwise, the Earth, which is constantly being damaged by human behavior, may lose its balance. Human survival is also threatened. The current outbreak of the corona virus, according to Bernstein (2020), director of Harvard University's Center for Climate, Health and Global Environment is part of the impact of disrupting ecosystems on Earth due to human behavior. Deforestation, which occurs mostly for agricultural purposes, is the biggest cause of habitat loss worldwide. Loss of habitat forces animals to migrate and potentially interact with other animals or humans and share germs. Humans need to take action regarding climate change to prevent the next pandemic. One of them, prevent deforestation as a major cause of climate change, which can help stem the loss of biodiversity and slow down animal migration that can increase the risk of spreading infectious diseases.

Furthermore, Bernsteine (2020) suggests that "if humans are really concerned about preventing problems like this in the future, humans need to think hard about climate change and the biodiversity crisis". The solution shows that humans must live with more attention to the environment. Capra (2013) states that in the next few decades, the survival of mankind will depend on ecological literacy. Our ability to understand the basic principles of ecology and to live according to them. Current development progress is a dangerous thing if not accompanied by environmental awareness. Humans tend to exploit natural resources haphazardly without paying attention to the effect that caused (Rusmana \& Akbar, 2017). Steps are needed actually taken. When things continue continues, then there will be no time front. The younger generation from an early age must introduced to the awareness of environment, in order to create a society that cares about the environment. A number of an organization that cares about the environment have taken action. Counseling and seminars have been conducted in an effort make people aware about environmental problems. However, awareness government as the deciding party policy is paramount. One of the efforts that must be made government is to include awareness of the internal environment curriculum. The purpose of the application in order to create a society that is aware about the environment.

Within the framework of the 2013 curriculum, Indonesian language learning is designed as text-based learning that has a broad reach (Syukron, 2018). Indonesian language learning is the right vehicle to present content-based learning because it is a text-based learning. In text-based learning, students are invited to understand various ways of presenting ideas in various types of texts and then practice them in various language activities, in line with the practice of using Indonesian in everyday life which includes various purposes and situations (Mutiah, 2014). Indonesian language presents material in the form of texts that can be filled with Ecoliteracy content

Understanding of ecoliteracy must start early. Planting an environmentally friendly attitude is a must-have attitude every individual. This is in accordance with the opinion 
of Goleman (2012) that every individual who has awareness about the environment can synchronize development development with the environment so as to create an environment that harmony between society and environment. However, an attitude of caring for the environment will not come with itself, there needs to be an introduction and coaching so that this attitude can be ingrained flesh on students. The development of good ecological literacy skills, applying them in daily life, committed to responding to climate change and the biodiversity crisis, then the preservation of the earth and sustainable life can be realized. One way to instill ecoliteracy in elementary school students is to use appropriate and efficient interaction media for students in the early grades of elementary school. It is in accordance with Najib et al. (2019) that if learning media is developed, used and utilized appropriately, it will provide enormous benefits in the teaching and learning process.

Media in learning is a component that has an influence on achieving learning objectives. Learning media plays an important role in increasing the success of the learning process (Fahmi, 2017). The use of media in teaching and learning activities students will be more motivated to learn. This is in accordance with what was stated by (Nugraha et al., 2016), motivated individuals are individuals who have a focus on the importance of effort and persistence in learning. The availability of media will also enable students to actively participate in learning activities. This is in accordance with the principles of teaching and learning as in the Curriculum and Learning book, Hamalik (2015) suggests that one of the principles of teaching and learning is that students learn by doing and experiencing firsthand and active involvement in the learning environment. Classes with the availability of media in their learning will produce different students from classes that do not provide media in their learning. Students with learning to use media will be much more active than students who in learning never use media at all. In contrast to their 'passive' classmates, proactive students self-regulate seeking information and adopt whatever actions are necessary to control it (Nugraha et al., 2016).

Learning media can also be used according to user characteristics, both individually and in groups. Brown suggests that educational media of all kinds have a role and allow students to benefit from these media even in individual learning. Media creation can be adapted to the characteristics of media users. In a traditional/rural school environment, long-term learning planning requires structured planning, selected media resources can also be scheduled regularly.

Learning media can be packaged in the form of children's story books equipped with pictures that match the topic in the story. The addition of images in each story must look at the characteristics of each story so that it can represent something that is implied in the story. Picture story books have a plot that really tells the story, illustrations in picture story books have as important a role as the text. Availability of images in each This story is expected to be able to give the reader an initial picture to guess about the story to be read. Picture story books should be evaluated according to the quality of the pictures and stories. Learning that uses story books as a medium in the learning process, it would be nice if the process of using the story is continuous so that students will find it easier to understand the story. According to the statement of Carr and Lee (2012), when I started writing lessons using stories using new indicators, I became aware that the stories that really excite me are generally new stories that are illustrated 
by more than one indicator. Positive character values in children's stories can be used as learning for children who read them (Nurmanita et al., 2017).

This picture story book is also very popular among children because of its attractive appearance. Children's stories are stories of appropriate events that can be reached and understood by children's readers (Nurjanah \& Hakim, 2018). The process of making this picture story book must also be in accordance with the initial goals that were previously designed. To understand why picture books should be such an important part of children's environments, it is important to identify some of the purposes they serve. The development of this picture story book must be in accordance with the characteristics of the children and the initial goals that have been prepared so that it will produce a story book that is as expected in the initial plan. In addition, there are advantages in using this picture story book in accordance with the opinion of Stewig (Nurgiyantoro, 2005), Three unique features of using picture story books are that they provide language input for children, they provide visual input for children, and they stimulate children's visual and verbal fluency. The availability of this story book can also stimulate a love of reading in children.

Interesting stories for children should stimulate imagination, help develop intelligence, clear emotions, and adjust to anxiety when he is faced with finding a way out. Stories for children should relate to children. For example, fairy tales that reflect a child's view of the world. Storybooks are one of the most preferred media by children, especially those that have illustrations and a few games (interactive books) that involve children, so children will feel like they are in the story (Jesse et al., 2015). The advantages of books are: (1) Touchable, a book is an object that provides information in a tangible form that can be touched and in its own environment it can be a decoration that decorates a room; (2) Trusted Reference Sources, Indeed, not all references in books can be trusted, but in making literature reviews for scientific works, books play an important role in providing additional material for writing; (3) Economical, by having one's book one can also save money because in using one's book one does not need to pay for electricity to search for information.

Knowledge of the environment that students have can make students environmentally friendly, so they can find effective solutions to environmental problems encountered (Prastiwi et al., 2019). This is also reaffirmed by Supriatna explaining that ecoliteracy is important to develop in the learning process because students have a role as agents who develop knowledge, insight, attitudes and sustainable behavior in society (agents of change), agents who have awareness of their natural conditions and agents who can apply ecoliteracy in life. As an agent of change, one's environmental knowledge must be realized in concrete actions as an effort to protect the environment. Without the realization in the form of real action, environmental knowledge only becomes knowledge whose application is not sustainable (Sitorus \& Lasso, 2021). The environment plays an important role in realizing the attitude and responsibility of caring for the environment. This is because through education, students are regulated in speaking, acting or behaving that shows good character (Auliyairrahmah et al., 2021).

This study is relevant to the research conducted by Hartati et al. (2020) that The lack of student interest in literature results in low student literacy. One way to increase students' literacy and ecological awareness is through children's literature. Therefore, 
ecoliteracy-based children's literature books are considered to be used as learning support books, media and language learning resources for elementary schools. Another study conducted by Rusmana \& Akbar (2017) that learning the introduction of ecoliteracy is the introduction of students to the environment directly, it is hoped that with students doing activities directly it will foster a love for the environment. Research aims to produce an interactive storybook containing ecoliteracy education for elementary school students of good quality in terms of the validity, practicality, and effectiveness of a product.

\section{RESEARCH METHOD \\ General Background}

Type This research includes Research and Development (R\&D) research. According to Sugiyono (2016) Research and Development (R\&D) is a research method used to produce certain products and test the effectiveness of these products. Meanwhile, according to Putra (2015) Research and Development (R\&D) is a research method intentionally, systematically, to find, improve, develop, produce, or test the effectiveness of products, models, and methods/strategies/ways that are superior, new, effective, efficient, productive, and meaningful. This research design uses the research and development design of the ADDIE (Analysis, Design, Development, Implementation, Evaluation) model developed by Branch (2009). The ADDIE development model was chosen because it is effective, dynamic and supports the performance of the program itself. The main purpose of this research is to develop interactive story books for ecoliteracy learning for elementary school students of good quality in terms of the validity, practicality, and effectiveness of a product.

\section{Partisipants}

The research subjects for the development of interactive storybooks for ecoliteracy learning in early elementary school students are 30 students in first grade and second grade at Elementary School (SDN Balas Klumprik, Wiyung District, Surabaya City) in the 2021/2022 academic year.

\section{Instrument and Procedures}

Instruments and procedures used in this study are 1) Validation sheet as an assessment given by the validator by ticking $(\sqrt{ })$; 2)The observation sheet on the implementation of learning and student activities is used to obtain practical data on student worksheets in supporting learning activities. Questionnaire sheets were given to teachers to provide an assessment of the products developed; 3) Learning outcomes test sheets were used to obtain data on the effectiveness of using interactive story books for ecoliteracy learning for early grade elementary school students (Astutik \& Prahani, 2018).

The first step is the analyze stage, the analysis stage is a stage of gathering information that can be used as material to make products, in this case the resulting product is interactive story book. This information collection is in the form of needs analysis, student characteristics analysis, and 2013 curriculum analysis. The second step is the design stage, at this stage the designinteractive story bookdesigned to facilitate researchers in designing the products developed. The product design stage is the learning implementation plan (i.e. RPP), the formulation of indicators, learning objectives and draftinginteractive story books for ecoliteracy learning. The third step is 
the develop stage, which is the stage of the process of developing something that has been made in the design stage to become a product. The final result of this stage is a product that will be tested.

The fourth step is the implementation stage. at this stage the designinteractive story bookthat have been developed are implemented in real situations, namely in the classroom (learning process). During implementation, the game design that has been developed is applied to actual conditions. After the implementation in the field, an initial evaluation is carried out to provide feedback on the application of the next model. The implementation phase is carried out on students at elementary school of Balas Klumprik Surabaya. During the trial, the researcher made notes about the shortcomings and obstacles that still occurred when the product was implemented. The last step is to evaluate, namely process for analyzing usage interactive story bookfor ecoliteracy learning that has been developed at the implementation stage there are still shortcomings and weaknesses or not. Suggestions and inputs from expert validators are also used as references and considerations by researchers. If there are no further revisions, then the product is suiTable for use.

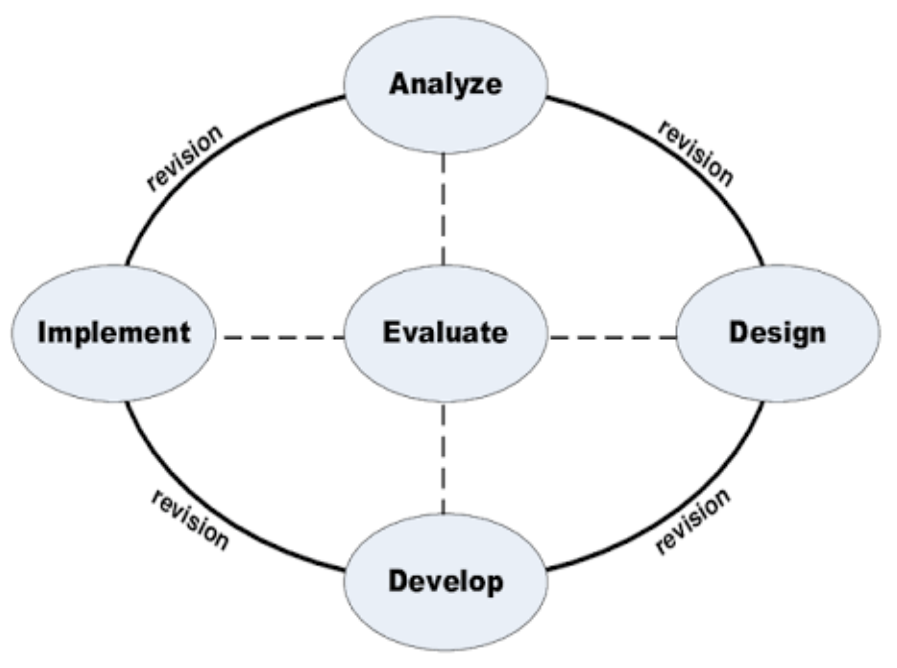

Figure 1. Flowchart ADDIE model.

\section{Data Analysis}

Product development data obtained frominteractive story bookwhich has been validated by experts/media experts and material experts. The results of the assessment were concluded in a qualitative descriptive form using Likert's reference. Likert's reference Table 1.

Table 1. Validation rating scale.

\begin{tabular}{cc}
\hline Score & Criteria \\
\hline 1 & Not good \\
2 & not good \\
3 & Pretty good \\
4 & Well \\
5 & Very good \\
\hline
\end{tabular}

(Riduwan, 2013) 
The data generated from the validation is in the form of a score. The percentage of agreement between validators is calculated using the percentage of agreement $(\mathrm{R})$, with the formula:

Information:

$$
R=\frac{\sum K}{\sum N}
$$

$\mathrm{R}=$ Average

$\mathrm{K}=$ Number of aspects assessed

$\mathrm{N}=$ Total number of aspects

The results of data analysis on each aspect of the average score are then interpreted into the following Table 2 .

Table 2. Validiton percentage criteria.

\begin{tabular}{cc}
\hline Average score & Category \\
\hline $0 \%-20 \%$ & Very less \\
$21 \%-40 \%$ & Not enough \\
$41 \%-70 \%$ & Enough \\
$71 \%-80 \%$ & Good/decent \\
$81 \%-100 \%$ & Very good/very decent \\
\hline
\end{tabular}

(Riduwan, 2013)

Observational data were obtained from observing the activities of teachers and students during the implementation of online learning by using zoom. The results of observations in the form of scores using Likert's reference as Table 3.

Table 3. Observation rating scale.

\begin{tabular}{cc}
\hline Score & Criteria \\
\hline 1 & Not good \\
2 & Not good \\
3 & Pretty good \\
4 & Well \\
5 & Very good \\
\hline
\end{tabular}

(Riduwan, 2013)

The scores obtained from the observations then processed using the following formula.

$$
p \%=\frac{\text { jumlah total score of data collection result }}{\max \text { score }} \times 100 \%
$$

The percentage of observations is used to determine the implementation of the learning process when using interactive story books. After the percentage results are obtained then interpreted based on the following criteria Table 4 .

Table 4. Observation percentage criteria.

\begin{tabular}{ccc}
\hline No. & Average score & Category \\
\hline 1. & $0 \%-20 \%$ & Very less \\
2. & $21 \%-40 \%$ & Not enough \\
3. & $41 \%-70 \%$ & Enough \\
4. & $71 \%-80 \%$ & Well \\
\hline
\end{tabular}


Development of Interactive Story Book For Ecoliteration Learning in Early Class Students Elementary School

$5 . \quad 81 \%-100 \% \quad$ Very good

(Riduwan, 2013)

The data from the questionnaire were obtained through a questionnaire from the teacher's assessment of the interactive storybook for ecoliteracy learning in early grade elementary school students that was developed. The measurement scale of the questionnaire data uses the Guttman scale reference. The Guttman scale is described in the following Table 5.

Table 5. Student questionnaire rating scale.

\begin{tabular}{cc}
\hline Answer & Score \\
\hline Yes & 1 \\
No & 0 \\
\hline
\end{tabular}

(Riduwan, 2013)

The score obtained from the results of the teacher's assessment questionnaire, then processed using the following formula.

$$
p \%=\frac{\text { total score of data collection result }}{\max \text { score }} \times 100 \%
$$

(Riduwan, 2013)

The percentage of the questionnaire was used to determine the teacher's assessment of interactive story books for ecoliteracy learning in early grade elementary school students. After the percentage results are obtained then interpreted based on the following criteria Table 6.

Table 6. Student questionnaire percentage criteria.

\begin{tabular}{ccc}
\hline No. & Average score & Category \\
\hline 1. & $0 \%-20 \%$ & Very less \\
2. & $21 \%-40 \%$ & Not enough \\
3. & $41 \%-70 \%$ & Enough \\
4. & $71 \%-80 \%$ & Well \\
5. & $81 \%-100 \%$ & Very good \\
\hline
\end{tabular}

(Riduwan, 2013)

Analysis of the test data on learning outcomes for grade 1 and 2 elementary school students was analyzed using a gain score on the pretest and posttest scores. The magnitude of the increase was analyzed using the formula (Hake, 1999)

$$
<\mathrm{g}>=\frac{\text { posttest }- \text { pretest }}{\text { max score }- \text { pretest }}
$$

The gain scores obtained are interpreted into the n-gain categories in Table 7.

Table 7. Classification of N-Gain score.

\begin{tabular}{cc}
\hline Normalized gain value & Interpretation \\
$-1,00 \leq \mathrm{g} \leq 0.00$ & There is a decrease \\
$\mathrm{g}=0.00$ & No increase \\
$0,00<\mathrm{g} \leq 0.30$ & Low \\
\hline
\end{tabular}


Development of Interactive Story Book For Ecoliteration Learning in Early Class Students Elementary School
$0,30<\mathrm{g} \leq 0.70$
$0,70<\mathrm{g} \leq 1,00$
Currently
Tall

Research and development of the products developed, namelyinteractive story book for ecoliteracy learning in early grade elementary school studentsin the form of quantitative using pretest - posttest control group design. Pretest - posttest control group design pattern. The design is described as Table 8.

Table 8. Pretest-posttest control group design model schematic.

\begin{tabular}{cccc}
\hline $\mathrm{E}$ & $\mathrm{O} 1$ & $\mathrm{X}$ & $\mathrm{O} 2$ \\
\hline $\mathrm{C}$ & $\mathrm{O} 3$ & - & $\mathrm{O} 4$ \\
\hline
\end{tabular}

(Sugiyono, 2019)
Information:
$\mathrm{E}=$ Experiment Class
$\mathrm{C}=$ Control Class
$\mathrm{X}=$ Treatment interactive story book
- $\quad$ = Student book treatment
$\mathrm{O} 1=$ Result pretest experimental class
$\mathrm{O} 2$ = Result posttest experimental class
$\mathrm{O} 3=$ Result pretest control class
$\mathrm{O} 4=$ Result posttest control class

Data analysis in this study used the independent $\mathrm{t}$-test formula to determine the effectiveness of the interactive storybooks for ecoliteracy learning that were developed. Statistical analysis, including parametric statistical tests, must meet the prerequisite tests, namely normality tests and homogeneity tests. The level of significance used in this study is 0.05 . This analysis prerequisite test aims to determine whether or not there are deviations from the existing variables. After the prerequisite test is done, then the independent sample t-test t-test analysis is carried out using SPSS.

\section{RESULTS AND DISCUSSION}

Research and development of interactive storybooks that were developed according to the needs of teachers in ecoliteracy learning to increase reading interest in early elementary school students. This interactive story book contains various stories and readings based on the surrounding environment according to the development of students. It aims to foster students' interest in reading and students' understanding of the concern for the natural environment around them. This research produces interactive storybooks for application in everyday life. The mirror book clarifies the problems that occur in the environment in a concrete and complete manner so that students can understand and take attitudes to overcome problems that occur in their daily lives (Amilyana et al., 2021). This research was carried out online due to the Covid-19 emergency so that learning in schools is no longer done face-to-face. Face-toface online learning is carried out with the help of the Google Meet platform. This picture story book is also very popular among children because of its attractive appearance. Children's stories are stories of appropriate events that can be reached and understood by children's readers (Nurjanah \& Hakim, 2018). Interesting stories can stimulate the imagination, help develop intelligence, clear emotions, and adjust to anxiety when faced with finding a way out. This is reinforced by the opinion of Jesse et 
al. (2015) that story books are one of the most preferred media by children, especially those that have illustrations and a few games (interactive books) that involve children, so children will feel like they are in the story.

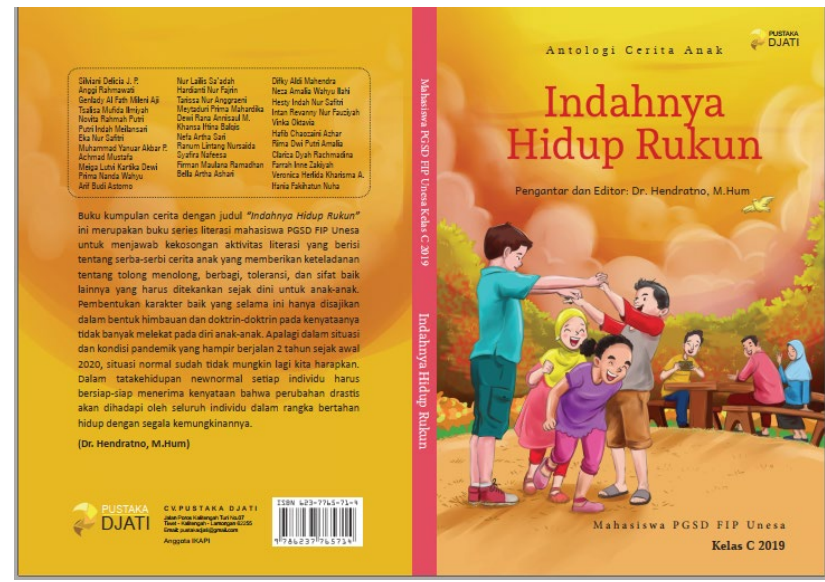

Figure 2. Interactive storybook front and back cover I.

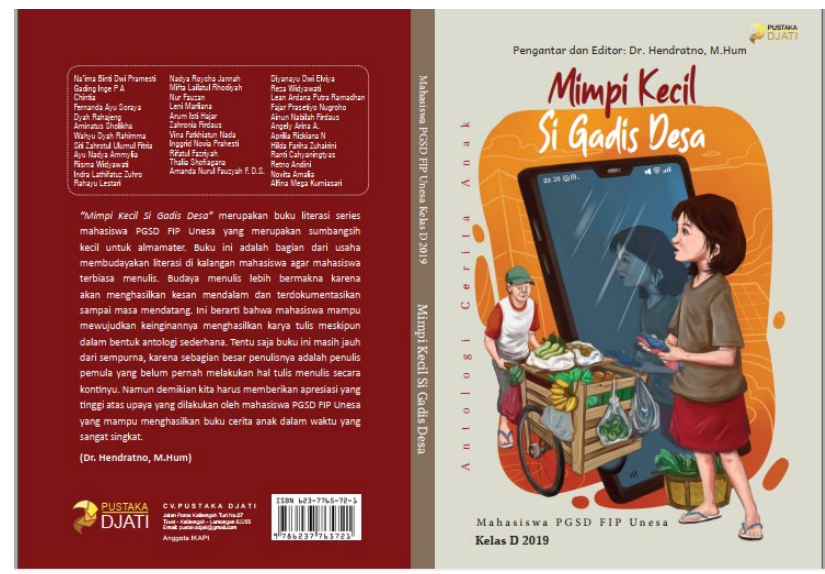

Figure 3. Interactive storybook front and back cover II.

Validity of Interactive Story Book

Before being used to collect research data, the instruments used must be validated first by experts in their fields. All of the instruments that were validated were the validation of interactive storybooks covering content/materials, graphics and language; RPP validation; validation of learning observation sheets; teacher response questionnaire sheet; validation of the learning outcomes test sheet. The results of the validation by the validator are presented in Table 9.

Table 9. Research instrument validation results by experts.

\begin{tabular}{llcl}
\hline No. & \multicolumn{1}{c}{ Validated instruments } & Average score & Predicate \\
\hline 1. & Interactive storybooks include material, graphics, & 3.73 & Very valid \\
& language & & \\
2. & Lesson plan & 3.68 & Very valid \\
3. & Learning observation sheet & 3.73 & Very valid \\
4. & Response questionnaire Lembar & 3.65 & Very valid \\
5. & Study result test sheet & 3.65 & Very valid \\
\hline
\end{tabular}


From the validation results, it can be seen that the overall instrument used for the study obtained a very valid category because it was in the range of values of 3.6-4.0. The validity of the interactive folklore book for early grade ecoliteracy learning is carried out to determine the feasibility level of a product being developed, can be categorized as very good qualifications based on the Likert scale reference in determining the criteria for the validation results in this study (Riduwan, 2013). The instrument developed is declared valid or invalid using an instrument in the form of a validation sheet which will be filled in by an expert in their field called a validator to find out the drawbacks of the instrument being developed and suiTable for use (Yusuf, 2018).

Product can be said if it has a quality measure if it meets several aspects of product quality. The product developed in this research and development based on the assessment of expert validators has shown that all aspects tested have a very good product validity score. This statement is in accordance with the opinion expressed by Nieveen (1999) that a product can be said to be of quality if it meets the product quality aspects, including (1) validity; (2) practicality; (3) effectiveness. The interactive folklore book "Banyubiru" can be used at all levels of education. This is in accordance with Najib et al. (2019) that the ability of teachers to master classes where students have different characters requires learning aids such as interactive story books to focus students when the teacher explains learning. This is in line with the opinion of Faizah who stated that picture story books are basically effective in increasing reading abilities and interests.

\section{Practicality of Interactive Story Book}

The product practicality assessment includes the implementation of learning, student activities and teacher assessment of the interactive folklore book "Banyubiru" that has been developed. In the condition of the Covid-19 pandemic, face-to-face learning activities in schools cannot be carried out, so learning activities are carried out online through the Zoom application and Google Classroom. The results of the implementation of learning and student activities derived from the observer's assessment are stated as Table 10.

Table 10. Practicality recapitulation results.

\begin{tabular}{|c|c|c|c|c|c|c|}
\hline No. & Rated aspect & & Implementation & Average & Percentage & Information \\
\hline 1 & $\begin{array}{l}\text { Implementation } \\
\text { learning }\end{array}$ & of & Pretest & 3.00 & $75 \%$ & $\begin{array}{l}\text { Very well } \\
\text { executed }\end{array}$ \\
\hline 2 & $\begin{array}{l}\text { Implementation } \\
\text { learning }\end{array}$ & of & Posttest & 3.77 & $91 \%$ & $\begin{array}{l}\text { Very well } \\
\text { executed }\end{array}$ \\
\hline 3 & Student activities & & Pretest & 3.1 & $77 \%$ & Active \\
\hline 4 & Student activities & & Posttest & 3.8 & $94 \%$ & Active \\
\hline
\end{tabular}

The learning activities in the first meeting (pretest), the implementation stage received a score from the two observers as a whole, obtaining a percentage of $75 \%$ in the very good category, while at the second meeting (posttest) it obtained a percentage of $91 \%$ in the very good category. The results of the observation of children's activities at the first meeting got a score from two observers overall getting a percentage of $77 \%$ in the active category, while children's activities at the second meeting got a percentage value of $94 \%$ in the active categoryin excellent qualification (Riduwan, 2013). 
Product can be said to be practical if it makes it easier for users to use or use the product. The products produced in this development research were tested to determine the level of practicality of a product. The test results can be seen from the observations of 2 observers. The negative behavior of students, especially related to lack of focus in learning activities, is greatly reduced, meaning that the ecoliteracy learning program uses interactive story books "banyubiru" as a practical learning tool in improving students' understanding. This is in accordance with the opinion Tryanasari \& Kartikasari (2021) that psychomotor programs are used to channel excess energy to students and specialization programs. To build students' literacy skills, activities that are integrated and synergized between learning in the classroom and outside the classroom can be used and involve many parties (Abidin et al., 2017). Basically, the development of students' abilities is a shared responsibility between the school and the community as stated in the principles of the school literacy movement.

Furthermore, the results of the teacher's assessment response questionnaire to the interactive folklore book "Banyubiru" were developed. The results of this questionnaire were filled out by 2 grade 1 teachers and 2 grade 2 elementary school teachers. Based on the results of the teacher's assessment of the interactive folklore book "Banyubiru" with an average percentage of $97 \%$. This means that the interactive folklore book "Banyubiru" for early grade students' ecoliteracy learning can be said to be very practical. According to Putra (2015) in addition to being valid, the product developed must be practical and effectively used in learning

Sardiman (2014) argues that in learning there needs to be activity, because in principle learning is doing or learning by doing. Activity is a principle or principle that is very important in learning interactions. In essence, learning is more than just remembering. A child really understands and can apply science, they have to work hard to solve problems, find something and always be in touch with ideas or ideas. The learning process that is expected to occur according to Aunurrahman (2013) is a process that can develop the potential of children in a comprehensive and integrated manner. For this reason, in the learning process teachers are not only required to deliver subject matter, but must be able to actualize their strategic role in an effort to shape children's character through personality development and prevailing values.

\section{Effectiveness of Interactive Story Book}

EffectivenessInteractive folklore book "Banyubiru" for students' ecoliteracy learning The initial class developed by the researcher can be seen from the results of the tests given, namely the initial test (pretest) and the final test (posttest). The design in this research and development uses a pretest-posttest control group design. In the experimental class, the interactive folklore book "Banyubiru" treatment was given, while the control class used conventional learning which is usually done by the teacher.

The effectiveness of the product can be seen from the results of increasing the ability of children from before being given treatment (pretest) and after being given treatment (posttest). This is in accordance states that learning outcomes are used to find out how far a person accepts or understands the material or material that has been delivered. In this research and development, the effectiveness is seen from the learning outcomes test. 
Development of Interactive Story Book For Ecoliteration Learning in Early Class Students Elementary School

Table 11. Recapitulation of student learning result.

\begin{tabular}{clccc}
\hline \multirow{2}{*}{ No. } & \multicolumn{1}{c}{ Description } & \multicolumn{2}{c}{ Maximum Score $=\mathbf{1 0 0}$} \\
& & Pretest & Posttest \\
\hline 1. & Average & 74 & 0.67 & 90.8 \\
2. & N-Gain & & & 100 \\
3. & The highest score & 85 & 55 \\
4. & Lowest Value & 55 & & 55 \\
\hline
\end{tabular}

Data analysis used an independent t-test to answer the problem formulation and objectives in research on the effectiveness of the developed interactive folklore book "Banyubiru", where statistical analysis including parametric statistical tests must meet prerequisite tests, namely normality test and homogeneity test. The error rate (significance level) used in this study was 0.05 . The purpose of this analysis prerequisite test is to determine whether there are deviations from the existing variables. Testing the normality of the data on the difference in learning outcomes for elementary school students at the pretest and posttest using the development of interactive storybooks was carried out using Shapiro-Wilk, with the criteria if the probability value $>$ level of significance (alpha $=5 \%)$ then the data on the difference in the value of the fourth grade narrative writing skills pretest and posttest elementary schools using the development of digital-based learning media non-fiction texts are declared normal (Sundayana, 2014; Priyatno, 2014). The results of the normality test of the difference in the value of the narrative writing skills of fourth grade elementary school students pretest and posttest using the development of digital non-fiction text-based learning media can be seen in the following Table 12 .

Table 12. Normality test results.

\begin{tabular}{clcc}
\hline Group & \multicolumn{1}{c}{ Variable } & Significance (p) & Information \\
\hline Control & Pretest learning outcomes & 0.267 & Normal \\
& Posttest learning outcomes & 0.280 & Normal \\
\hline \multirow{2}{*}{ Experiment } & Pretest learning outcomes & 0.170 & Normal \\
& Posttest learning outcomes & 0.292 & Normal \\
\hline
\end{tabular}

Based on the Table above, it can be seen that the significance value for the pretest and posttest learning outcomes for early elementary school classes in the control and experimental groups is greater than 0.05 , so the research data is declared to be normally distributed (Sundayana, 2014). Homogeneity test can be done using Levene's test, by looking at the significance level of the calculated Levene value. If the Levene value shows a significance level of more than 0.05 (Sundayana, 2014), it can be said that there is no difference in variance between the sample groups or in other words, the variance between groups is the same. The results of the homogeneity test can be seen in the following Table 13.

Table 13. Homogeneity test results.

\begin{tabular}{cccc}
\hline & Class & Significance & Information \\
\hline Pretest & $\begin{array}{c}\text { Control } \\
\text { Experiment } \\
\text { Control } \\
\text { Experiment }\end{array}$ & 0.287 & Homogeneous \\
\hline
\end{tabular}


Based on the Table 13, the homogeneity test in the pretest obtained a value of 0.387 which means greater than 0.05 , while the posttest homogeneity test shows a value of 0.671 which means greater than 0.05 . From the two data, it can be said that there is no difference in variance between sample groups or in other words the variance between groups of pre-test and post-test variables for learning outcomes is the same or homogeneous (Sundayana, 2014; Sugiyono, 2019).

The requirements for parametric statistical tests consisting of normality tests and homogeneity tests have been met, so that the next stage of analysis can be carried out. Prerequisite analysis has been done, the next step is to analyze the data. Data analysis technique using independent testwith the criteria that if the probability is (5\%) then $\mathrm{H} 0$ is rejected (Sugiyono, 2019; Priyatno, 2014). Because the learning outcome variable meets the assumption of normality, the independent $t$ test is used to test the research hypothesis which reads "There is a difference in understanding of the understanding of ecoliteracy by using the interactive folklore book "Banyubiru" for early elementary school grades".

Table 14. Hypothesis testing results.

\begin{tabular}{lllll}
\hline & t count & & Sig. $(\mathbf{p})$ & \multicolumn{1}{c}{ Information } \\
\hline Pretest & 1,468 & 0,147 & There is not any \\
Posttest & 4,676 & 0,017 & There's a difference \\
\hline
\end{tabular}

Based on Table 14, the calculation using the significance test on the pretest value of this study obtained tcount of 1,468 with a significant of 0,147 . So, it can be concluded that the significance value $(\mathrm{p})>0,05$ then $\mathrm{Ha}$ is rejected, so that during the pretest it can be concluded that there is no significant difference before using the interactive folklore book "Banyubiru"for early grade ecoliteracy learningprimary school. Meanwhile, based on the posttest value Table in this study, a significance value of $<0,05(0.017<0,05)$, the conclusion is Ha is accepted, so it can be concluded that after treatment in the form of an interactive folklore book "Banyubiru" there are differences in the understanding of ecoliteracy of early elementary school students. .The effectiveness of the product can be seen from the results of giving tests given to students, so learning outcomes are very important to measure learning effectiveness (Rasyid et al., 2019). In this research and development, the effectiveness can be seen from the results of the tests given to students through pretest and posttest using interactive story books. Interactive story books developed by researchers can support the function of books as an intermediary learning resource in delivering information and understanding students. Munadi (2013) states that "learning resources" have the meaning as transmitters, distributors, and liaisons so that learning resources can be understood by students which facilitates the process.

Human survival is very dependent on sustainability natural. However, the harmony of nature for several centuries began to be disturbed because some humans tend to overexploit nature. In addition, almost every day humans also leave waste inorganic materials that are not easily recycled by nature (Syukron, 2018). Learning activities in Schools are the upstream of strategic human resource development facilities in create an environmentally friendly human. In this vision, ecoliteracy is appropriate for scenarios and integrated in a learning. Ecoliteracy is defined as a literal activity that leads to understanding and developing a critical attitude towards sustainability environment. Through ecoliteracy, students will be habituated to be critical, 
responsive, and innovative to problems related to components balancer of an ecosystem, at least in the environment in which they are stay.

Storybooks are one of the most preferred media by children, especially those that have illustrations and a few games (interactive books) that involve children (Jesse et al., 2015), so children will feel like they are in the story. The following are the advantages of books, namely 1) Touchable, books are one of the objects that provide information in a tangible form that can be touched and in the book's environment itself can be in the form of decorations that decorate a room; 2) Reliable reference sources, indeed not all references in books can be trusted, but in making literature reviews for scientific works, books play an important role in providing additional material in writing; 3) Save money, in owning a book one can also save money because in using a book one does not need to pay for electricity to find information.

Availability of media according to the topic of learning becomes the center of attention that the teacher must pay attention to to be able to present media in every learning process. This makes the children become fond of learning while playing with the media fun and educational (Rahmawati, 2016). The implementation of teaching and learning activities using this interactive storybook can be used independently group or independently. In this interactive story book also presented the stages of writing the story correctly and accompanied by: with examples so that it will make it easier for students to learn how to write stories correctly. Presentation of stages the writing is adjusted to the order in writing the story so that students do not need to choose the stages again. Other than that, In the story book, interesting pictures are also presented and presented in colors that match the characters picture. This will have an impact on student interest in learning. This is evidenced by the enthusiasm of students in using this interactive storybook in teaching and learning activities. As stated by Palaiologou (2013) that children should be able to learn through the experience of touching, moving, listening, and seeing.

The use of interactive story books also makes students actively work in groups with their friends, both in one group and other groups (Nugraheni et al., 2019). In interactive story books there are group assignments that must be done with their group friends and exchange opinions with other groups. Use of book media This story makes students active in learning, and the teacher acts as a facilitator and guides the use of media. That matter According to Edwards et al. (2013), we are interested in teachers who identify something as the conceptual basis of their engagement with children and the pedagogical strategies they would like to use with children when using something different from either the type of pedagogical play related to childhood education early childhood, including games that open students' minds as well as games that are deliberately framed.

\section{CONCLUSIONS}

Based on the results of the research and discussion that have been described previously, the following conclusions can be stated that the quality of the interactive storybooks developed are very valid, practical and effective for use in learning. This research produced a story book containing ecoliteracy education for elementary school students. Research related to learning literary appreciation needs to be done with various variations, including developing interactive serial books for ecoliteracy learning. 
Interactive storybooks are meant to be storybooks that do not only present text, but also have a variety of illustrations that are interesting for students and if possible there is a dialogue process in the book. Ecoliteracy urgently needs to be studied and become the collective intelligence of mankind. For further researchers, can develop books or similar learning media with improvements in various ways to get more optimal results, especially books or media that can foster an attitude of caring for the environment from the elementary school level.

\section{REFERENCES}

Abidin, Y., Mulyati, T., \& Yunansah, H. (2017). Developing literacy learning model based on multi literacy integrated, and differentiated concept at primary school. Cakrawala Pendidikan: Jurnal Ilmiah Pendidikan, 36(2), 156-166. https://doi.org/10.21831/cp.v36i2.13283

Amilyana, A. Z., Noer, T. K. M. S., \& Rahardjo. (2021). A teaching material based on science, environment, technology and society to improve students's critical thinking skills: Synchronous and asynchronous learning during covid-19 pandemic. IJORER: International Journal of Recent Educational Research, 2(4), 372-391. https:// doi.org/10.46245/ijorer.v2i4.109

Aunurrahman. (2016). Belajar dan pembelajaran. Bandung: Alfabeta.

Astutik, S., \& Prahani, B. K. (2018). The practicality and effectiveness of collaborative creativity learning (CCL) model by using phet simulation to increase students' scientific creativity. International Journal of Instruction, 11(4), 410-424.

Auliyairrahmah, A., Djazilan, S., \& Hartatik, S. (2021). Implementasi pendidikan karakter integritas sub nilai kejujuran melalui program kantin kejujuran di sekolah dasar. Edukatif: Jurnal Ilmu Pendidikan, 3(6), 3565-3577. https:// doi.org/10.31004/edukatif.v3i6.939

Bernsteine, A. (2020). Coronavirus, climate change, and the environment. Harvard C-CHANGE.

Branch, R. M. (2009). Instructional design: the addie approach. New York: Spinger Science \& Business Media.

Capra, F. (2013). Deep ecology: Educational possibilities for the twenty first century. The NAMTA Journal, 38(1), 201-216.

Carr, M., \& Lee., W. (2012). Learning stories constructing learner identities in early education. London: British Library Cataloguing in Publication Data.

Edwards, S., Cutter, A., \& Mackenzie. (2013). Pedagogical play types: What do they suggest for learning about sustanability in early childhood education?. International Journal of Early Childhood, 45(3), 327-346. https://doi.org/10.1007/s13158-013-0082-5

Fahmi, S. (2017). Pengembangan media pembelajaran interaktif untuk kursus logika matematika dan set. Prosiding Konferensi Internasional Ahmad Dahlan tentang Pendidikan Matematika, 5(1), 1-8.

Goleman, D. (2012). Ecological intelligence: How knowing the hidden impacts of what we buy ccn change everything. US: Jossey Bass.

Hake, R. R. (1999). Analyzing change/gain scores. Woodland Hills: Department of Physics, Indiana University.

Hamalik, O. (2015). Kurikulum dan pembelajaran. Bandung: Bumi Aksara.

Hartati, T., Andriani, E. N., Supriatna, N., \& Nuriyanti, R. (2021). Development of children's literature book based on primary school students' ecoliteration. Social, Humanities, and Educational Studies (SHEs): Conference Series, 4(1), 152-160.

Jesse, A., Bramantya., \& Sutanto, R. P. (2015). Perancangan buku cerita interaktif untuk menimbulkan minat baca anak usia 4-6 tahun. Jurnal DKV Adiwarna, 1(6), 1-13.

Munadi, Y. (2013). Media pembelajaran (sebuah pendekatan baru). Jakarta: Referensi. 
Development of Interactive Story Book For Ecoliteration Learning in Early Class Students Elementary School

Mutiah, A. (2014). Representasi pendekatan whole language dalam sajian materi pembelajaran bahasa indonesia berbasis teks. Prosiding Semnas Bahasa, Sastra, dan Pembelajarannya. Yogyakarta: Gress Publishing.

Najib, D. K., Ulfa, S., \& Sulthoni. (2019). Pengembangan media pembelajaran interaktif kearifan lokal banyuwani untuk siswa kelas V. Jurnal Kajian Teknologi Pendidikan, 2(1), 75-81. http:/ / dx.doi.org/10.17977/um038v2i12019p075

Nieveen, N. (1999). Prototyping to reach product quality. in Plomp, T; Nieveen, N; Gustafson, K; Branch, R.M; and van den Akker, J (eds). Design approaches and tools in education and training. London: Kluwer Academic Publisher.

Nugraha, R., Degeng, S., Hanurawan, F., \& Chusniah, T. (2016). Process of self regulated learning an student's strategic studies activities in learning environment. International Conference on Education: Education in the 21thCentury: Responding to Current Issues, 2016(1), 747-753.

Nugraheni, I., Harsiati, T., \& Qohar, A. (2019). Media buku cerita untuk meningkatkan kemampuan membaca dan menulis siswa kelas IV sekolah dasar. Jurnal Pendidikan: Teori, Penelitian dan Pengembangan, 4(3), 322-329. http:/ / dx.doi.org/10.17977/jptpp.v4i3.12085

Nurgiyantoro, B. (2005). Sastra anak: Pengantar pemahaman dunia anak. Yogyakarta: Gadjah Mada University Press.

Nurjanah, E., \& Hakim, D. (2018). Pengembangan bahan ajar materi mencerna (menyimak cerita anak) berbasis cerita anak majalah bobo pada siswa kelas vi MI Darum Najah I Jatirejo Mojokerto. Jurnal Bidang Pendidikan Dasar, 2(1), 69-83.

Nurmanita, T., Harsiati, T., \& Suyono. (2017). Cerita anak sebagai sarana pendidikan karakter di sekolah dasar. Prosiding TEP E PDs Transformasi Pendidikan Abad 21, 7(9), 1100-1105.

Palaiologou, I. (2013). The early years foundation stage theory and practice second edition. Wasington DC: SAGE Publications Ltd.

Prastiwi, L., Sigit, D. V., \& Ristanto, R. H. (2019). Ecological literacy, environmental awareness, academic ability and environmental problem-solving skill at adiwiyata school. Indonesian Journal of Science and Education, 3(2), 82-92. https://doi.org/10.31002/ijose.v3i2.1114

Priyatno, D. (2014). SPSS 22 pengolah data terpraktis. Yogyakarta: Andi Offset.

Putra, N. (2015). Research $\mathcal{E}$ development (penelitian dan pengembangan). Jakarta: Raja Grafindo Persada.

Rahmawati, I. (2016). CD Interaktif sebagai media pembelajaran berbahasa bagi anak usia dini di Ponorogo. Jurnal INDRIA: Ilmiah Pendidikan Pra Sekolah dan Sekolah Awal, 1(1), 9-21. https://doi.org/10.24269/jin.v1n1.2016

Rasyid, M., Aziz, A. A., \& Saleh, A. R. (2016). Pengembangan media pembelajaran berbasis multimedia dalam konsep sistem indera pada siswa kelas xi sma. Jurnal Pendidikan Biologi, 7(2), 69-80. https://doi.org/10.17977/um052v7i2p69-80

Riduwan. (2013). Skala pengukuran variabel-variabel penelitian. Bandung: Alfabeta

Rusmana, N. E., \& Akbar, A. (2017). Pembelajaran ekoliterasi berbasis proyek di sekolah dasar. Jurnal Edukasi Sebelas April, 1(1), 1-12.

Sardiman, A. M. (2014). Interaksi dan motivasi belajar mengajar. Jakarta: Raja Grafindo Persada

Sitorus, L., \& Lasso, A. H. (2021). Pendidikan karakter peduli lingkungan melalui pembiasaan dan pembudayaan di sekolah menengah pertama. Edukatif: Jurnal Ilmu Pendidikan, 3(5), 2206-2216. https://doi.org/10.31004/edukatif.v3i5.755

Sugiyono. (2016). Metode penelitian kuantitatif, kualitatif dan RED. Bandung: CV Alfabeta.

Sugiyono (2019). Statistika untuk penelitian. Bandung: CV Alfabeta.

Sundayana. (2014). Statistika penelitian pendidikan. Bandung: Alfabeta.

Syukron, A. (2018). Ekoliterasi: Desain pembelajaran bahasa indonesia berwawasan lingkungan. FKIP E-Proceeding, 2018(1), 61-70. 
Development of Interactive Story Book For Ecoliteration Learning in Early Class Students Elementary School

Tryanasari, D., \& Kartikasari HS, A. (2021). Program ekoliterasi sebagai upaya meningkatkan fokus siswa slow learner di SDN 2 Sukowinangun kabupaten Magetan. PTK: Jurnal Tindakan Kelas, 2(1), 132-140. https:// doi.org/10.53624/ptk.v2i1.57

Utama, A. (2019). Jawa 'kehabisan air' tahun 2040: Ratusan juta orang terancam bencana yang 'tak pernah terbayangkan'. BBC News Indonesia.

Waughray, D. K., \& Nath, K. (2020). Why 2020 is the year to reset humanity's relationship with nature. World Economic Forum.

Yusuf, F. (2018). Uji validitas dan reliabilitas instrumen penelitian kuantitatif. Jurnal Tarbiyah: Jurnal Ilmiah Kependidikan, 7(1), 17-23. https://doi.org/10.18592/tarbiyah.v7i1.2100

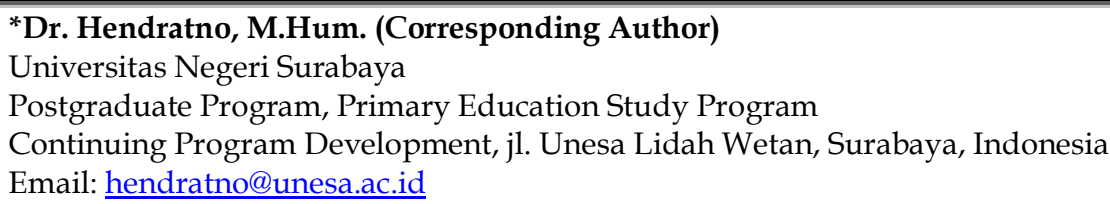

